\title{
Transmutation of Spiritual Credence During COVID-19 Era in Cancer Patients: A Case Series
}

\author{
Seema Mishra, Raghav Gupta, Sachidanand Jee Bharti, Swagata Biswas
}

Department of Oncoanaesthesia \&Palliative Medicine, Dr. BR Ambedkar Institute Rotary Cancer Hospital, All India Institute of Medical Sciences, Delhi, India.

\begin{abstract}
Background: COVID-19 pandemic has afflicted cancer patients on various fronts including spiritual domain. The case series tries to highlight the spiritual beliefs and challenges faced by cancer patients and the transformation which has occurred during pandemic. Methods: Thirty consecutive cancer patients who attended outpatient clinic of cancer pain and palliative department were assessed on spiritual front through nine questions and on the basis of which their perception about spirituality, health problems, role of pandemic in transformation of spiritual beliefs and their coping mechanisms were analyzed. Results: Most respondents related spirituality to almighty. Half of the cases blamed karma, fate and God for their suffering. Signs of transformation in spiritual credence during pandemic was evident in the form that majority could not attend their places of worship, were having lack of spiritual clarity and developed feeling of fatalism. For coping with the stress and anxiety majority resorted to path of prayer and chanting at home, with few having belief in helping out others and participating in spiritual community sessions to overcome their problems in life. Conclusion: Spiritual domain of the patients is often an overlooked component by the clinicians during their examination. But maintaining a good spiritual health is as important as physical health for an overall better outcome in cancer patients and should be catered for providing a holistic care.
\end{abstract}

Keywords: Spirituality- cancer- COVID-19

Asian Pac J Cancer Care, 5 (Suppl 1), 129-132

\section{Introduction}

The Corona Virus disease 2019 also known as "COVID-19" was declared a pandemic by WHO on $12^{\text {th }}$ March 2020 [1]. It has created havoc all over the globe and impacted every country on various fronts including economic, social and political [2]. In India also the count is rising steadily. The patients with underlying serious health conditions for example cancer, have an increased risk of admissions into intensive care units [3-4]. The estimated case fatality rate in cancer patients with COVID- 19 is $6 \%$, [5] as compared to $1 \%$ among the general population [6]. With the estimated number of cancer cases in India being approximately 2.25 million the impact of this pandemic on cancer patients will be grave affecting both survival as well as quality of life [7]. The diagnosis of cancer in itself creates a feeling of desolation in patient's life. It not only affects the physical and mental well-being of
Submission Date: 07/06/2020Ａcceptance Date: 08/08/2020

\footnotetext{
Corresponding Author:

Dr. Seema Mishra

Department of Oncoanaesthesia \&Palliative Medicine, Dr. BR Ambedkar Institute Rotary Cancer Hospital, All India Institute of Medical

Sciences, Delhi, India.

Email: seemamishra2003@gmail.com
}

the patient and the caregivers but also affects the spiritual domain. Patient through the whole journey of cancer diagnosis and treatment undergoes myriad of emotions with numerous questions arising in mind on meaning and purpose of life. Spirituality has been defined as, 'An inherent quality of all human beings that drives the search for meaning and purpose in life, involves relationships with oneself, others, and a transcendent dimension [8]. It has been identified as an important pillar of health and well-being of the cancer patients and leads to improved quality of life with the help of spiritual practices like meditation [9]. There is paucity of literature exploring the spiritual beliefs and challenges faced by cancer patients during the novel COVID-19 pandemic. Through this case series we would like to highlight the transformation that has happened in the spiritual beliefs of cancer patients 
during this pandemic. On the basis of our assessment we also suggest few solutions which can be incorporated by the clinicians in their practice to help the patients overcome the spiritual dogma.

\section{Materials and Methods}

Thirty consecutive cancer patients who attended the outpatient department of cancer pain and palliative clinic of a tertiary care centre were included in our case series. Basic demographic information in form of age, gender and address was noted along with diagnosis and ECOG (Eastern Cooperative Oncology Group) performance status. The spiritual assessment was done with the help of nine questions which assessed the spiritual and religious beliefs, the level of distress they were undergoing and their coping mechanism (Table 1).

\section{Results}

Out of thirty respondents, fourteen were females and sixteen were males. Table 2 highlights the site of malignancies of the patients. Eight cases $(26.66 \%)$ belonged to ECOG (Eastern Cooperative Oncology Group) physical status III, rest twenty two cases $(73.33 \%)$ belonged to ECG II.

Sixty percent (18) of the patients when asked about their perception of spirituality answered that they feel it is a sense of connection to some higher power or almighty. Seventeen percent (5) of patients felt that spirituality is connecting with oneself and others. For equal number (5) of respondents' spirituality gives them purpose of life (Figure 1).

Regarding the perception of patients about their health problems fifty percent (15 cases) did not blame anyone for their disease or the current ongoing COVID pandemic and said that they are sad about what is happening with them and what is happening around in the world. One third (10 cases) of the respondents blamed it on destiny and karma together. Only two cases blamed God for all the sufferings (Figure 2).

The COVID-19 pandemic has brought tremendous change in the spiritual practices of the cancer patients. Eighty three percent of cases (25) felt that they are not able to go out to their religious places to devote time to God. Fifty percent of cases (15) felt that there is lack of

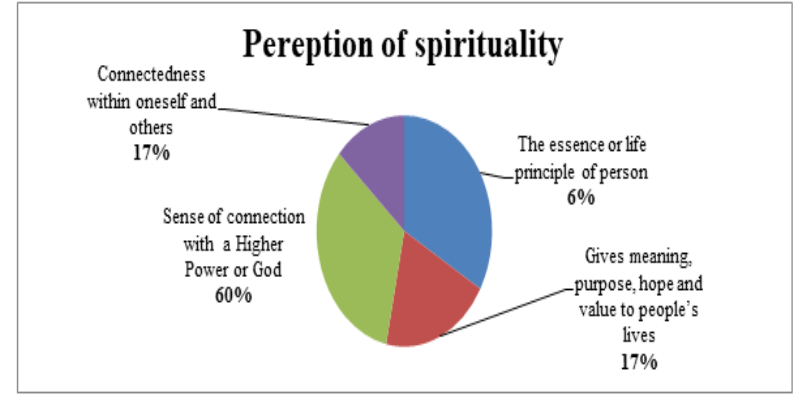

Figure 1. Perception of Spirituality

Table 2. Details of Site of Malignancies

\begin{tabular}{lc}
\hline Site of Malignancy & Number of cases (Percent) \\
\hline Head and Neck Cancers & $8(27 \%)$ \\
Genitourinary cancers & $4(13 \%)$ \\
Hepatobiliary cancers & $3(10 \%)$ \\
Hematological malignancies & $3(10 \%)$ \\
Breast cancers & $7(23 \%)$ \\
Bone tumors & $3(10 \%)$ \\
Thoracic malignancies & $2(7 \%)$ \\
\hline
\end{tabular}

spiritual clarity. Seven cases had feeling of fatalism. Eight patients reported both lack of spiritual clarity and sense of fatalism Figure 3.

To deal with all the stress related to disease and ongoing COVID-19 pandemic patients also expressed their coping mechanisms. Fifty percent $(15$ cases $)$ felt that their belief in God gives them strength. Sixty six percent patients (20 cases) use praying or chanting to deal with the stress and anxiety. Eight patients were grateful for life in general and had no qualms about the whole disease. Seven patients felt that the there is immense role of their spiritual community programs and sessions in providing them strength which they are attending online nowadays. One sixth (5 in number) of cases felt that helping out other people in the times of need gives them solace (Figure 4). Sixty percent (18) of the respondents told that that the health care teams should address the spiritual concerns during the hospital visit.

Table 1. Spiritual Assessment Questions

\footnotetext{
1. What is your perception regarding spirituality?

2. What do you think is the cause of the health problems?

3. How do you cope with the stress and what is your source of peace?

4. How the spiritual belief helps in taking care of oneself?

5 . What is the role of the spiritual community in your life?

6. What are your current spiritual practices?

7. What gives you sense of fulfillment in life?

8. How has the pandemic affected the spiritual beliefs and practices?

9. Do you think that the health care team should address the spiritual concerns during the hospital visit?
} 


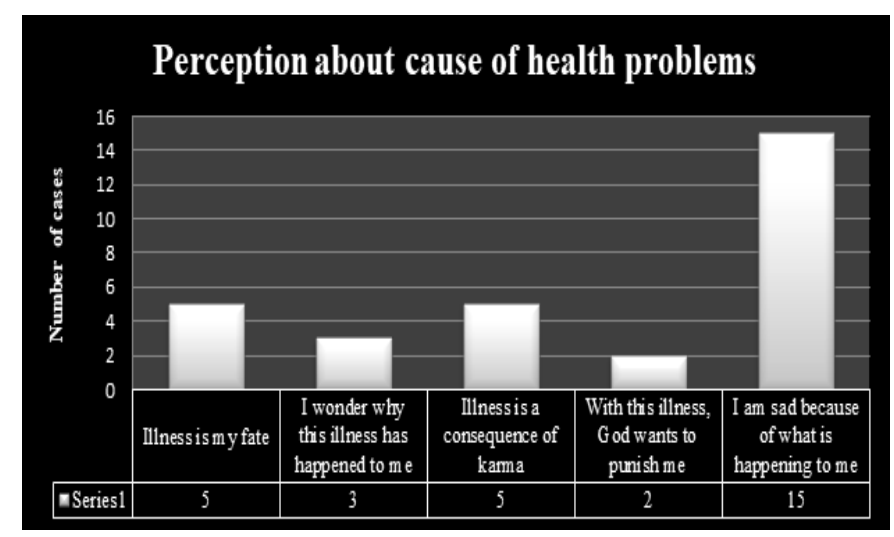

Figure 2. Perception about Cause of Health Problems

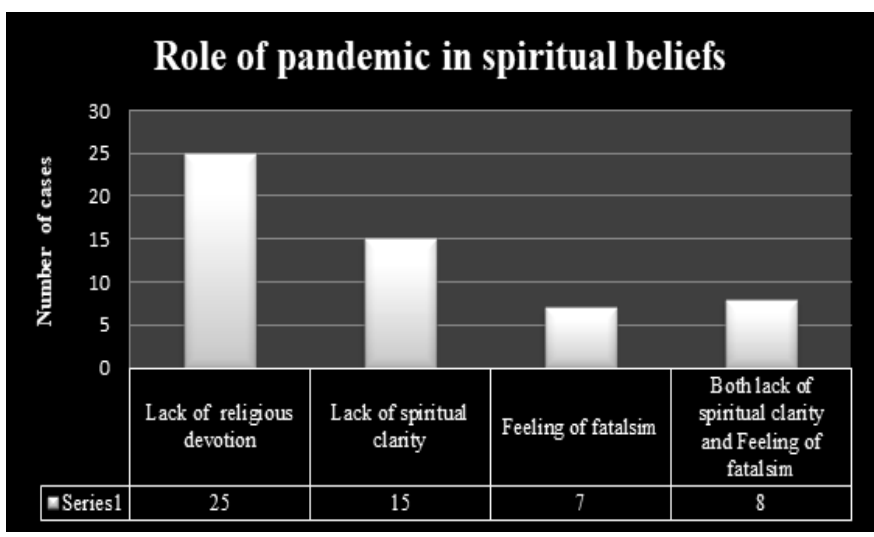

Figure 3. Role of Pandemic in Spiritual Beliefs

\section{Discussion}

Cancer patients and their caregivers face lot of hardships and challenges throughout the process of diagnosis and treatment. It takes a toll not only on the physical health but also on the emotional well-being. Ongoing novel coronavirus pandemic has made the task even more uphill for all the cancer patients. To deal with the emotional stress spirituality is often contemplated as a helping hand and makes decision making easier [10]. The case series tries to highlight four things- the perception of spirituality, the view point of the patients about their disease and ongoing pandemic, the transitional shift that pandemic has caused in their spiritual practices and their coping mechanisms. In our case series, majority patients felt that for them spirituality means connection with almighty. Even though religion and spirituality are two distinct entities but they are often conflated into one. Cohen et al [11] also suggested that religion is one of the components of spirituality and same is evident from our series. Half of the patients did not put blame on anyone about their disease, but at the same time the other half said that the current pandemic and all their sufferings is because of fate, their past karmas and because of almighty.

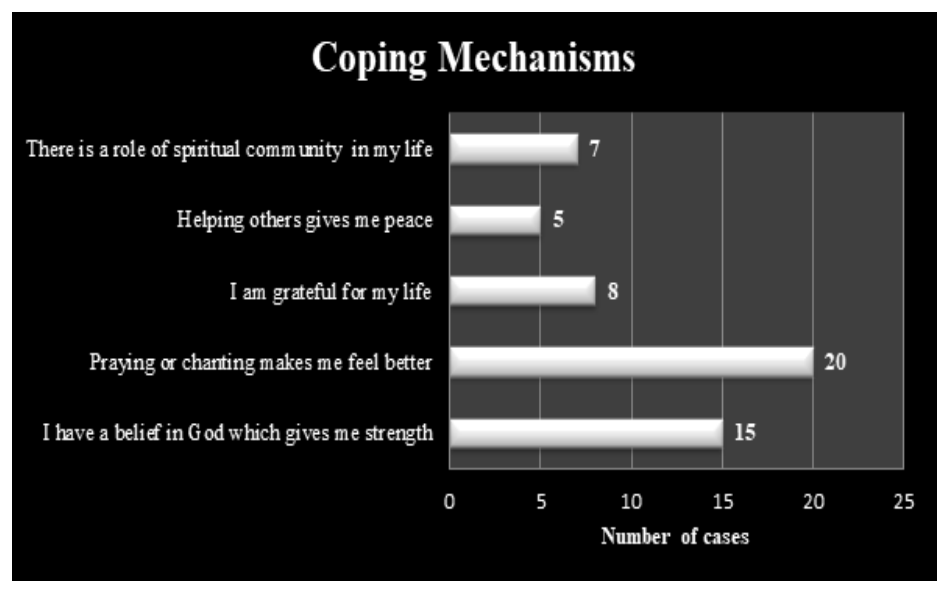

Figure 4. Coping Mechanisms 
This highlights the fact that almost all the patients are either worried about their situation or are trying to find answers to their problems through God. Almost sixty percent cases emphasized that they want the health care workers to discuss about their spiritual concerns and needs during their hospital visit which is often an overlooked component in our day to day clinical practice. It thus illustrates that spiritual issues needs to be addressed in the broader context in all the cancer patients [12]. It gives them a sense of belief and impetus to lead their life in a more positive way. As far as the COVID-19 pandemic is concerned, whole world has been inflicted, more so the patients who are suffering from debilitating illness like cancer. Cancer patients who are already striving hard to cope with their primary illness also have to worry now about getting affected by corona virus infection because of their immunocompromised state. Because of policies of nationwide lockdown majority respondents felt that they could not visit their religious places of worship, developed lack of spiritual clarity during these tumultuous times and had feeling of fatalism. People have been forced to remain indoors most of the time but now have started to pray from home and use liturgy and prayer resources provided to them. People have started to understand that compassion, kindness, sympathy and caring are the spiritual virtues that will help them to sail through. To deal with the stress and anxiety of disease and the pandemic, patients are using various coping mechanisms in the form of prayer and helping out others. Few were grateful to life in general whatever may be the circumstance in their life, rest felt that God and their spiritual community and sessions provided them strength and hope. After assessment of the spiritual needs, beliefs and challenges we suggest that all cancer patients should adopt spiritual care plans in the form of practices like meditation. They should try to follow their hobbies like art, craft, music, writing whenever feasible and should try to participate in spiritual community programs. From healthcare setup point of view clinicians should engage in the discussion about the spiritual concerns during the patient's visit to the hospital and may refer the patient to spiritual professional if he/ she wishes to. Clinicians may also adopt hope stimulating strategies in the form of developing interpersonal connect with the patient. Patients should be encouraged to attain small specific goals. This will ultimately help them in optimizing their courage, determination and serenity.

In conclusion, the case series highlight that addressing the spiritual needs is an important component of the whole treatment strategy in cancer patients. Cancer patients face lot of challenges on spiritual front also apart from the physical domain. COVID-19 pandemic has aggravated the challenges and problems the cancer patients are already facing. Cancer patients perceive spirituality in different ways, have different beliefs related to their disease and have different coping mechanisms but the novel corona virus pandemic has led to transformation and transmutation in their spiritual practices and beliefs. It thus becomes imperative for the health care professionals to understand the changing needs of the cancer patients and the care givers during the pandemic so that holistic health care services can be provided to them.

\section{References}

1. WHO. WHO announces COVID-19 outbreak a pandemic (2020). www.euro.who.int/en/health-topics/healthemergencies/coronavirus-covid-19/news/news/2020/3/ who-announces-covid-19-outbreak-a-pandemic..

2. del Rio C, Malani PN. COVID-19-New Insights on a Rapidly Changing Epidemic. JAMA. 202004 14;323(14):1339. https://doi.org/10.1001/jama.2020.3072

3. Zhou F, Yu T, Du R, Fan G, Liu Y, Liu Z, Xiang J, Wang Y, Song B, Gu X, Guan L, Wei Y, Li H, Wu X, Xu J, Tu S, Zhang Y, Chen H, Cao B. Clinical course and risk factors for mortality of adult inpatients with COVID-19 in Wuhan, China: a retrospective cohort study. The Lancet. 2020 03;395(10229):1054-1062. https://doi.org/10.1016/s01406736(20)30566-3

4. Liang W, Guan W, Chen R, Wang W, Li J, Xu K, Li C, Ai Q, Lu W, Liang H, Li S, He J. Cancer patients in SARSCoV-2 infection: a nationwide analysis in China. The Lancet Oncology. 2020 03;21(3):335-337. https://doi.org/10.1016/ s1470-2045(20)30096-6

5. Wu Z, McGoogan JM. Characteristics of and Important Lessons From the Coronavirus Disease 2019 (COVID-19) Outbreak in China. JAMA. 202004 07;323(13):1239. https://doi.org/10.1001/jama.2020.2648

6. Wu JT, Leung K, Bushman M, Kishore N, Niehus R, de Salazar PM, Cowling BJ, Lipsitch M, Leung GM. Estimating clinical severity of COVID-19 from the transmission dynamics in Wuhan, China. Nature Medicine. 202003 19;26(4):506-510. https://doi.org/10.1038/s41591-020-0822-7

7. Ingole S, Kakde A, Bonde P. A Review on Statistics of Cancer in India. IOSR J Environ Sci. 2016;10:107-16.

8. Hermann C. A Guide to the Spiritual Needs of Elderly Cancer Patients. Geriatric Nursing. 2000 Nov;21(6):324-325. https://doi.org/10.1067/mgn.2000.gn00324

9. Ferrell B, Hassey-Dow K, Leigh S, Ly J, Gulasekaram P. Quality of life in long term cancer survivors. Oncol Nursing Forum. 1995;22(6):915-22.

10. El Nawawi NM, Balboni MJ, Balboni TA. Palliative care and spiritual care. Current Opinion in Supportive and Palliative Care. 2012 06;6(2):269-274. https://doi.org/10.1097/ spc.0b013e3283530d13

11. Cohen Z, Headley J, Sherwood G. Spirituality and bone marrow transplantation: When faith is stronger than fear. Int J Human Caring Summer 2000;40-6. 2000;:40-6.

12. Borneman T, Ferrell B, Puchalski CM. Evaluation of the FICA Tool for Spiritual Assessment. Journal of Pain and Symptom Management. 2010 08;40(2):163-173. https:// doi.org/10.1016/j.jpainsymman.2009.12.019

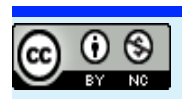

This work is licensed under a Creative Commons AttributionNon Commercial 4.0 International License. 